\title{
Ruptured frontal dermoid cyst: an unusual cause of seizure in a postpartum female
}

\author{
Hemanta K Nayak, Nitish L Kamble, Nitin K Sinha, Mradul Kumar Daga
}

Department of Medicine, Maulana Azad Medical College, New Delhi, India

\section{Correspondence to} Dr Hemanta K Nayak, drhemantnayak@gmail.com
To cite: Nayak HK, Kamble NL, Sinha NK, et al. BMJ Case Rep Published online: [please include Day Month Year] doi:10.1136/ bcr-2013-009107
A middle-aged woman who had given birth to her second child 9 days previously was admitted to the emergency department with two generalised tonic clonic seizures preceded by an intense headache with postictal confusion. She recovered within $30 \mathrm{~min}$ of hospitalisation. The history and physical examination were otherwise unremarkable, with no evidence of a vasculitic, hypercoagulable or embolic disorder. Her blood sugar, serum calcium and electrolytes were normal. She did not have any history of seizure, headache, vomiting or altered sensorium. Non-contrast CT revealed a large, wellcircumscribed hypodense mass involving the right frontal area (figure 1). Neuroimaging (MRI brain) revealed a well-defined, lobulated, extra-axial mass of size $4.5 \times 3.5 \times 3.5 \mathrm{~cm}$ in the right frontal region predominately hyperintense with hypointense area
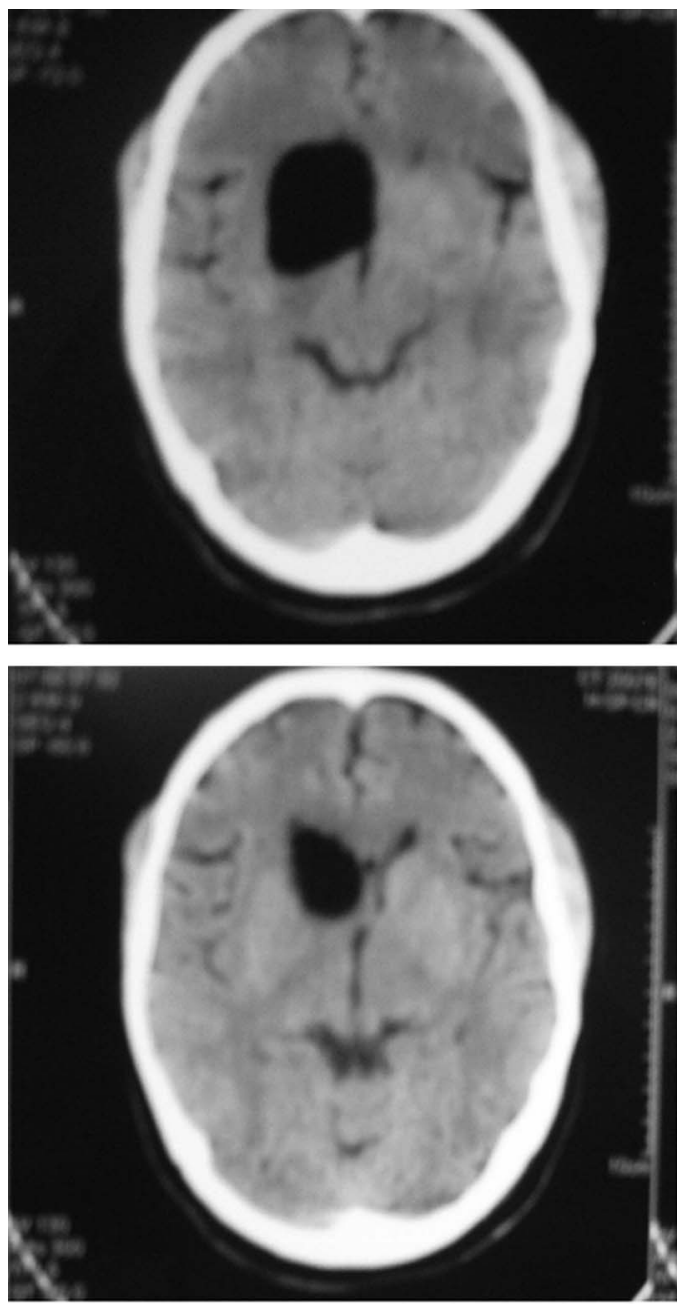

Figure 1 Non-contrast CT revealed a large, well-circumscribed hypodense mass involving the right frontal area. in the centre on T2 sequences and signalled suppression on fat saturated sequences (figure 2). A dermoid cyst was diagnosed in the right frontal lobe and was managed conservatively with an anticonvulsant (sodium valproate), a decongestant and antibiotics (for prevention of chemical meningitis).

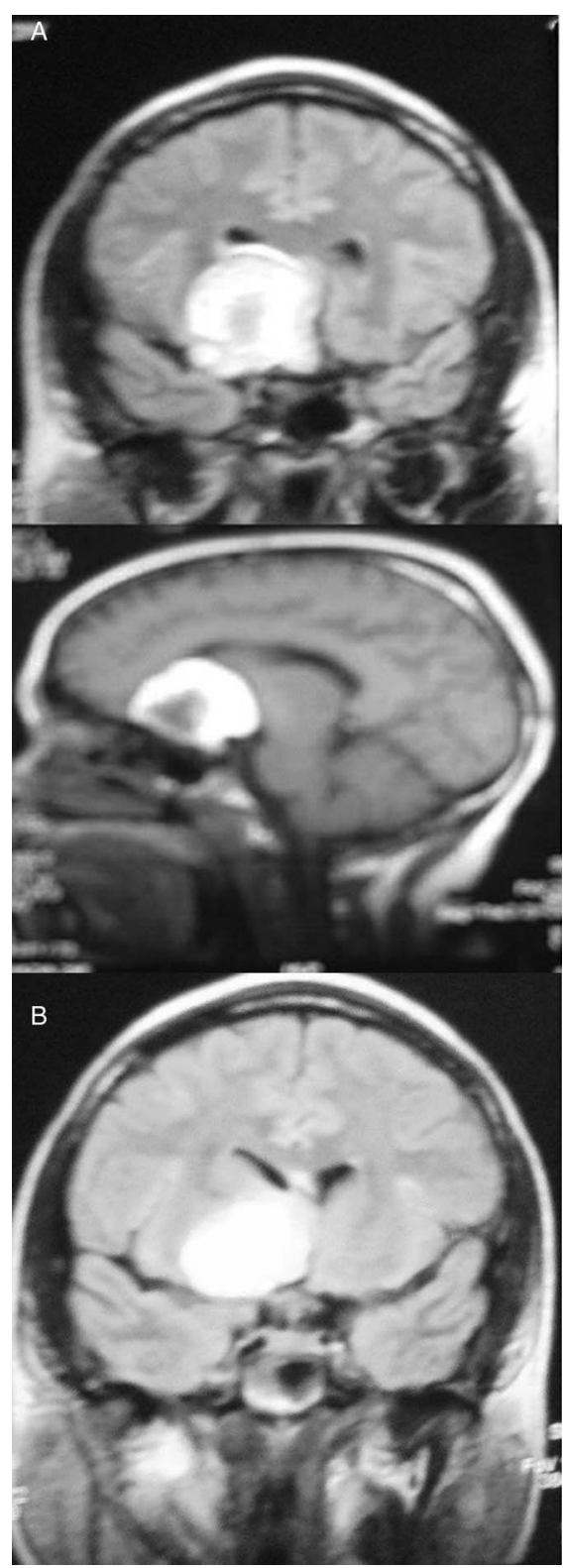

Figure 2 (A) Neuroimaging (MRI brain) reveals a well-defined, lobulated, extra-axial mass of size $4.5 \times 3.5 \times 3.5 \mathrm{~cm}$ in the right frontal region predominately hyperintense with hypointense area in the centre on $\mathrm{T} 2$ sequences and signal suppression on fat saturated sequences. (B) Neuroimaging (MRI brain) reveals a well-defined, lobulated, extra-axial mass in the right frontal region hyperintense lesions. 


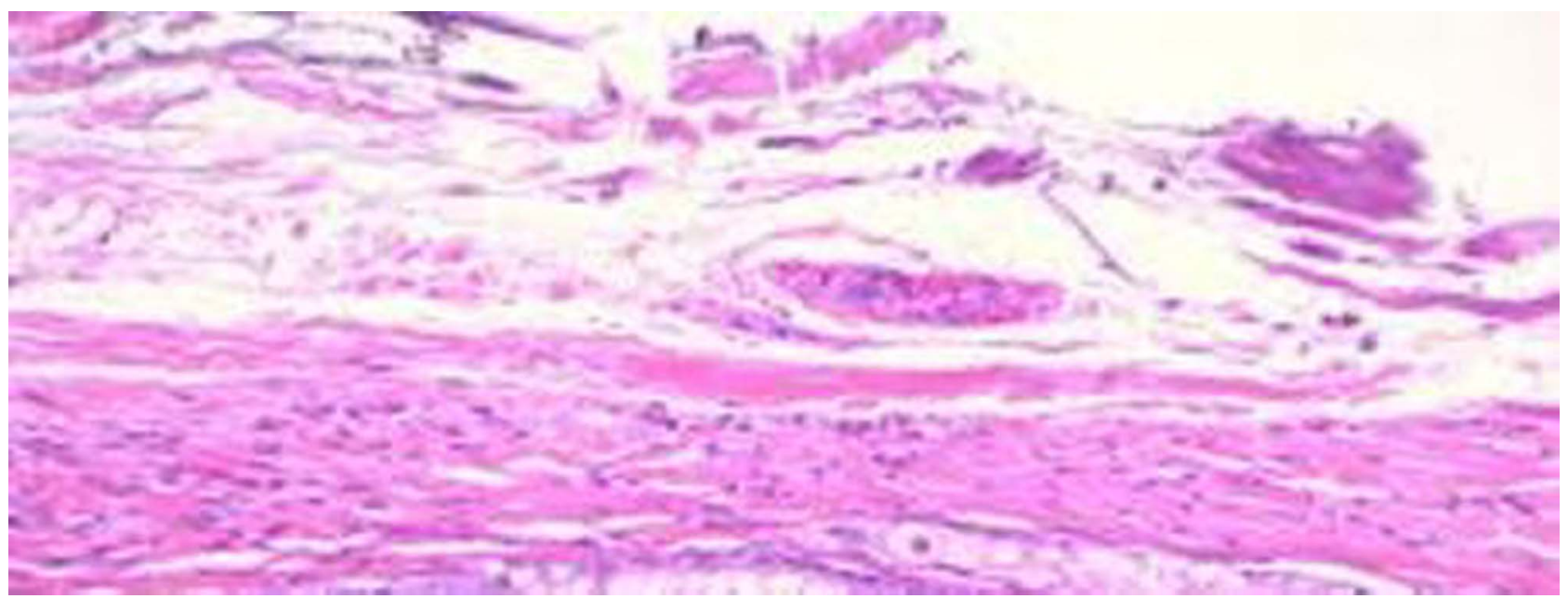

Figure 3 Microscopic examination of surgical specimen revealed keratinous material containing hair follicles.

It was transferred to neurosurgery for surgery and was found to be a large cyst with a partial rupture that was removed. On histopathology, it was found to be keratinous material containing hair structures confirming the diagnosis of a dermoid cyst (figure 3).

Intracranial dermoid cysts are rare, benign, slow-growing neoplasms and are believed to arise from ectopic ectodermal cell rests incorporated in the neural groove at the time of closure. ${ }^{1}$ Rupture of an intracranial dermoid cyst, although rare, occurs mostly spontaneously but may occur after head injury. ${ }^{2}$ It can lead to potentially serious and fatal complications in the form of headache, seizures and chemical meningitis. ${ }^{3}$ Our patient presented as a case of generalised tonic clonic seizure.

\section{Learning points}

- In a sick patient with seizures or headache, early imaging should be considered and a good knowledge base of imaging that allows the interpretation of rarer causes is important. The patient's clinical history, location of the lesion, presence of calcifications and low density on CT and demonstration of fat content on MRI favour the diagnosis of the dermoid.

- Headache, seizure and chemical meningitis are manifestations of a ruptured intracranial dermoid.

- Surgical removal of the lesion is advised for a large and symptomatic dermoid cyst. However, small and asymptomatic dermoid cysts can be followed up by MRI without surgical intervention.
Competing interests None.

Patient consent Obtained.

Provenance and peer review Not commissioned; externally peer reviewed.

\section{REFERENCES}

1 El-Bahy K, Kotb A, Galal A, et al. Ruptured intracranial dermoid cysts. Acta Neurochir (Wien) 2006;148:457-62.

2 Liu JK, Gottfried ON, Salzman KL, et al. Ruptured intracranial dermoid cysts: clinical, radiographic, and surgical features. Neurosurgery 2008;62:377-84.

3 Stendel R, Pietila TA, Lehmann $\mathrm{K}$, et al. Ruptured intracranial dermoid cysts. Surg Neurol 2002;39:18 
Copyright 2013 BMJ Publishing Group. All rights reserved. For permission to reuse any of this content visit http://group.bmj.com/group/rights-licensing/permissions.

BMJ Case Report Fellows may re-use this article for personal use and teaching without any further permission.

Become a Fellow of BMJ Case Reports today and you can:

- Submit as many cases as you like

- Enjoy fast sympathetic peer review and rapid publication of accepted articles

- Access all the published articles

- Re-use any of the published material for personal use and teaching without further permission

For information on Institutional Fellowships contact consortiasales@bmjgroup.com

Visit casereports.bmj.com for more articles like this and to become a Fellow 